肉盛溶接の高付加価値技術の 実際

\section{PTA 法によるアルミニウム合金表面 への厚膜硬化層の形成技術 ${ }^{*}$}

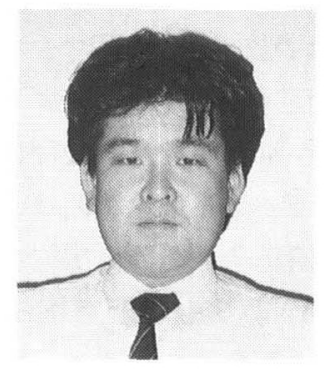

橋本 武 典**

\section{1. は じめに}

アルミニウムおよびその合金は，軽量であるために自動 車などの輸送機器関係に多く使われている.しかしなが ら，その使用環境はより過酷になり更なる性能の向上が要 求され，アルミニウムの高機能化が大きな技術課題となっ ている，その一つに耐摩耗性を中心とする表面改質技術が ある.ここでは, 特にプラズマアーク粉体肉盛法(Plasma Transferred Arc process：以下 PTA 法と略す）によるア ルミニウム合金の表面改質法について説明する.

\section{2. アルミニウム合金の耐磨耗性に必要な性能}

アルミニウム合金の耐磨耗性を向上させるために必要 な性能を簡単に述べる.

アルミニウム合金の耐磨耗性の向上は従来より多く研 究されており，種々の方法がある。一般には，硬質アル マイトやCrメッキ等があるが,これらは一般に硬質層 の厚さが薄く過酷な磨耗条件では十分な耐磨耗性が得ら れない.また, 逆にアルミニウム鋳物に代表される高シ リコン合金では材料全体が同一組成であり，耐磨耗性を 必要としない部分でも高シリコンとなり, 強度的な問題 が生じる（高価な合金を用いる場合はコストの面でも不 利になる.)

このような観点から，アルミニウム合金の耐磨耗性の 向上には局部的で，かつ比較的厚い硬化層を形成する必 要がある.

\footnotetext{
**正 員 昭和アルミニウム（株） Menber, Showa Aluminium corporation
}

\section{3. プラズマアークによる厚膜硬化層の形成の特徵}

プラズマアークによる厚膜硬化層は母材を溶融して, 硬 化層を形成するために母材との密着性が溶射などに比べ高 く，さらにミリオーダの厚膜硬化層が容易に形成できる.

厚膜硬化層の形成には，いくつかの熱源が用いられて いる．表 $1^{1}$ はこれらの熱源のパワー密度を示したもの である.

この表のように, プラズマアークのパワー密度はアー クとレーザ, 電子ビームの中間に位置する。 また, 装置 としても鉄鋼材料の肉盛装置としての実績があり，操作 性およU゙コストの面でも, レーザおよU゙電子ビームに比 して優れている.

さらに, PTA 法には以下のような特徵がある.

1）添加材に粉末を用いるのでワイヤやロッドにでき ない難加工材を硬化材料として利用できる.

2）炭化物などの非金属を複合させた，いわゆる“サー メット”の硬化層が得られる.

表 1 熱源のパワー密度

\begin{tabular}{c|c|c}
\hline \multicolumn{2}{c|}{ Power source } & Power density $\left(\mathrm{kW} / \mathrm{cm}^{2}\right)$ \\
\hline \multirow{3}{*}{ Arc } & Ar-arc & $<15$ \\
\cline { 2 - 3 } & Plasma arc & $50-100$ \\
\hline \multirow{3}{*}{ Electron beam } & pulse & $>10000$ \\
\cline { 2 - 3 } & continuous & $>1000$ \\
\hline \multirow{2}{*}{ Laser beam } & pulse & $>10000$ \\
\cline { 2 - 3 } & continuous & $>100$ \\
\hline
\end{tabular}


3）母材の溶け込みをコントロールしやすく，溶け込 みの少ない硬化も可能である。

4）ティグアークプロセスに比較してかなり高能率な 施工ができる。

5）平滑なビード形状が得られ，仕上げ機械加工の簡 略化が図れる。

6）大面積化が容易である。

\section{PTA 法による厚膜硬化層の形成}

プラズマアーク粉体肉盛法は, 従来より鉄鋼材料に対 する肉盛法として使用されており肉盛技術としては，奏 績のある方法である. 四 $1^{2} に$ にTA 法を模式的に示す.

PTA 法はプラズマアークにより母材表面層を一定移

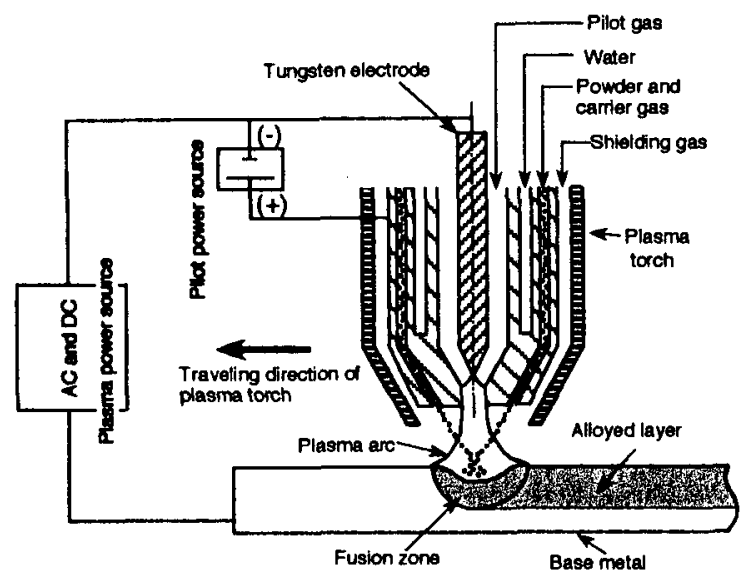

図 1 プラズマアーク粉体肉盛プロセスの概要
動速度で溶融し，同時にトーチ内から金属またはセラ ミックス粉末をプラズマアーク中を通して溶融池に供給 する。これにより溶融部に母材と供給された粉末との複 合硬化層を形成する。アルミニウム合金を对象としてい るためPTA 肉盛電源には，インバータ式交直雨用プラ ズマアーク溶接機が用いられる．放電極性とシールドガ スとの組み合わせは，実用的には交流十アルゴンガス (AC-Ar) と直流正極性十へリウムガス (DCEN-He) の 2 種類がある.図 $2^{3}$ は，それぞれの放電極性を用いた場合の 適正硬化層の形成条件とトー千移動速度の関係を示す。

困中の○印が，ビード表面が䯑らかで良好な硬化層の 得られる条件を示している。この適正条件範囲は一般的 にプラズマ電流が大きいほど適正条件範囲は広くなる。 また，DCEN-Heでは AC-Arよりもアーク電压が高 く,かつプラズマアーク集中性が良好なために, 同一電 流では高速度での形成が可能である。

\section{5. 金属粉末添加による硬化層の形成とその特性}

金属粉末添加では，溶融 $\mathrm{Al}$ との反応により硬化層を 形成し，主として硬質の $\mathrm{Al}$ 基金属間化合物などによ ク，硬化層の硬さを増加させる，このため硬化層の形成 にはアルミニウムと添加元素の状態図が大きく関係す る、共晶反応を有するものではアルミニウム溶融部全域 に均一に混合された組織であるが，包晶反応では溶融部 の表面層に局所的に金属間化合物が形成され，内部まで 混合されていない。各種金属粉末に対して検討した結果, 硬化層の形成は図 $3^{4}$ に示す 4 形態に分類される。

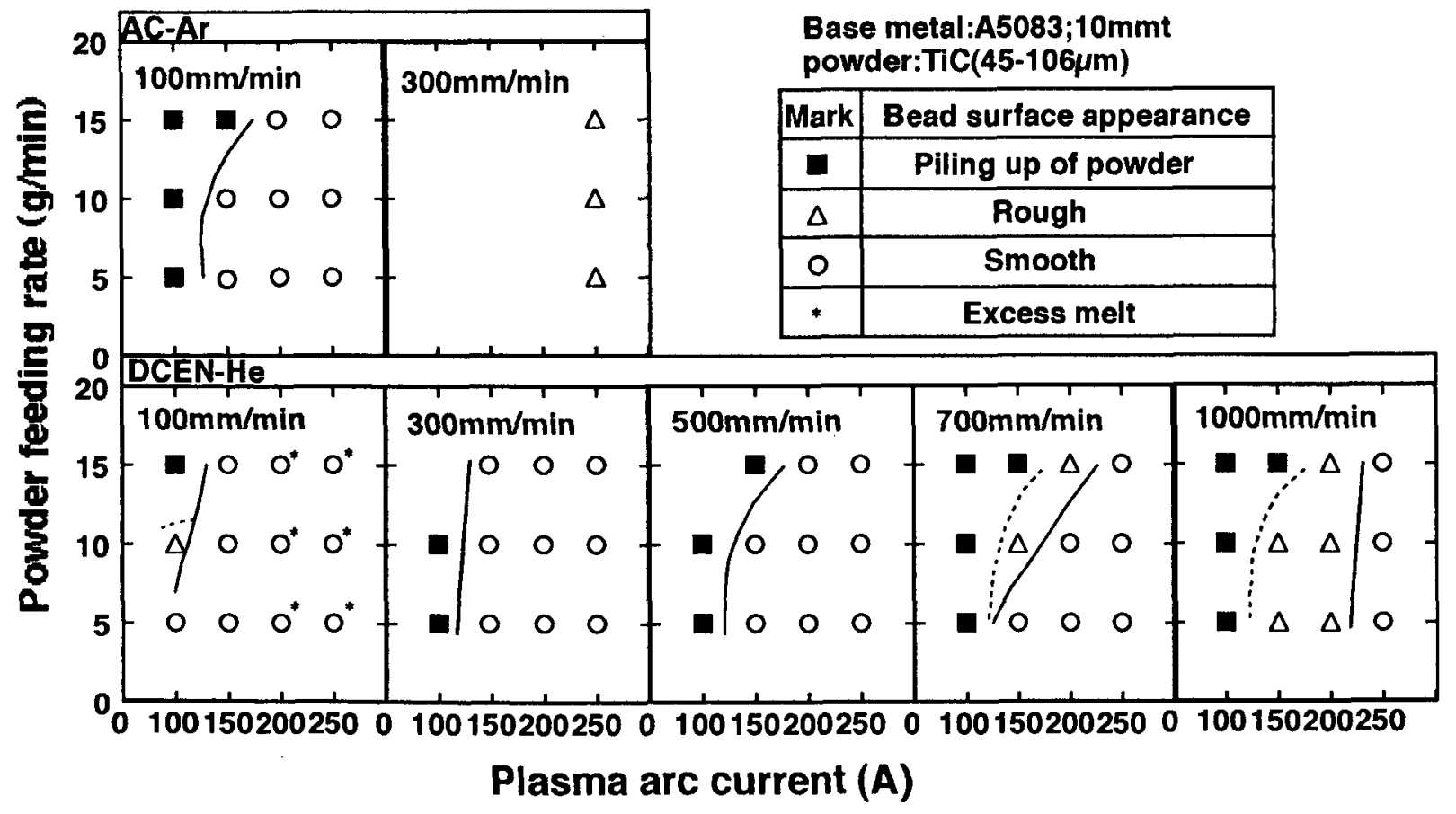

図 $2 \mathrm{AC}-\mathrm{Ar}$ お゙び DCEN-Heによる，適正策件範讲とトーチ移動速度の関係 
アルミニウムと共晶反応を有し液相温度も比較的低い 銅やシリコンでは均一な硬化層が得られるが，クロムや チタンのように包晶, 偏晶反応を有し, 液層温度の高い 金属粉末では，表面に化合物を形成し，均一な硬化層は 得られ難い。またニッケルのように包共晶反応を有する 場合には，両者の中間的な形態を示し，添加量が少ない 場合には比較的均一な硬化層が得られる。さらに，融点 が $3000^{\circ} \mathrm{C}$ を越えるタンタルやタングステンでは,アルミ ニウムと反応せずに硬化されることなく，後述するセラ ミックスと同様金属粒子のまま混合された形態となる.

図 4 は硬化層の合金量と硬さの関係を示す。合金量の 增加とともに硬さも増加する。しかし，HV 300 以上で は, 添加元素によらず硬化層には割れが発生し，金属添 加では硬さの増加には限界がある，金属元素の中では， 硬化層の形成の容易さおよび硬さの観点より，銅および シリコンが有効である。この結果は耐磨耗アルミニウム 合金の合金組成と同様の傾向を示している。

\section{6. セラミックス粉末添加による複合化層形成とその特性}

前述したように，金属系の合金化では硬化層の硬度が 高くなると割れが発生し耐磨耗性の改善には限界があ る.そこで硬化層として粒子分散複合層を形成すること による耐磨耗性の改善を試みた，特にPTA 法では前述 のように粉末状の添加は容易であるために硬化層の形成 には溶融池内へセラミックス粒子を添加することにより

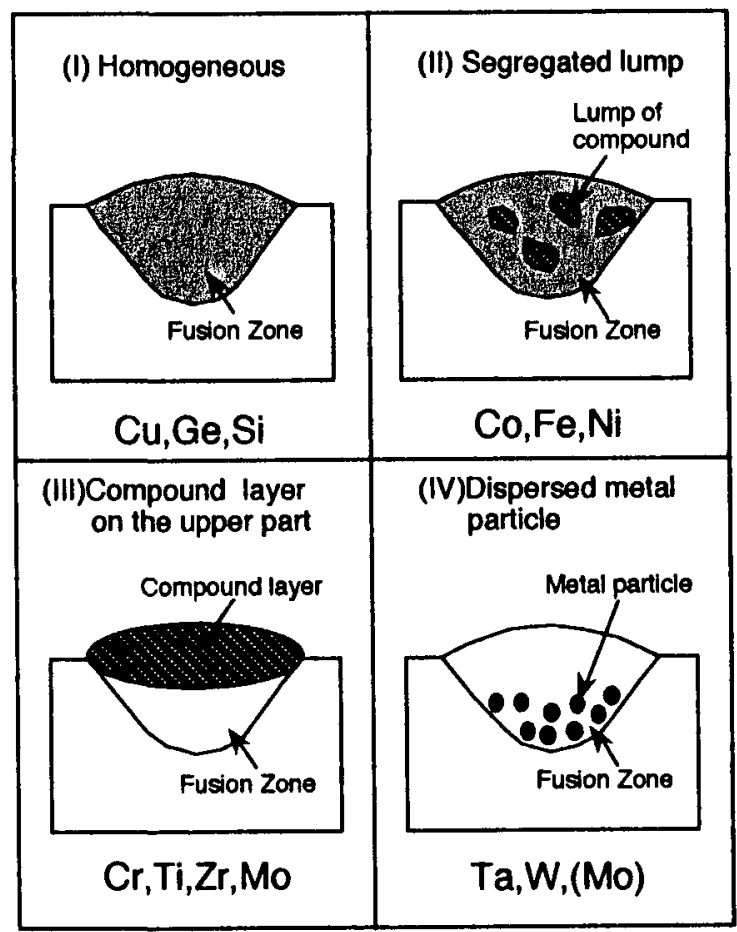

図 3 金属粉末添加により得られた硬化層の代表的な形態 分類（断面組織の模式図）
行うことができる、種々のセラミックスによる硬化層の 形成形態をまとめると図 5 のようになる.

セラミックスの融点が $2200 \sim 2500^{\circ} \mathrm{C}$ 以下では, $\mathrm{Cr}_{3} \mathrm{C}_{2}$ のような Type II (溶融した粒子が表面に堆積する)の形 態をとる.これ以上の融点を有するセラミックスでは， Type I の粒子分散複合化層を形成することが可能であ る, しかし複合化層内の粒子の分散状態は粒子の密度と 粒径が大きく影響する，図 $6^{5}$ はこの両者の関係を図示 したものである。

この図より均一分散層の形成はセラミックスの比重と 粒径により，ある程度まで制御可能であることがわかる。 また，粒子の高分散密度化は多層盛法で可能である。

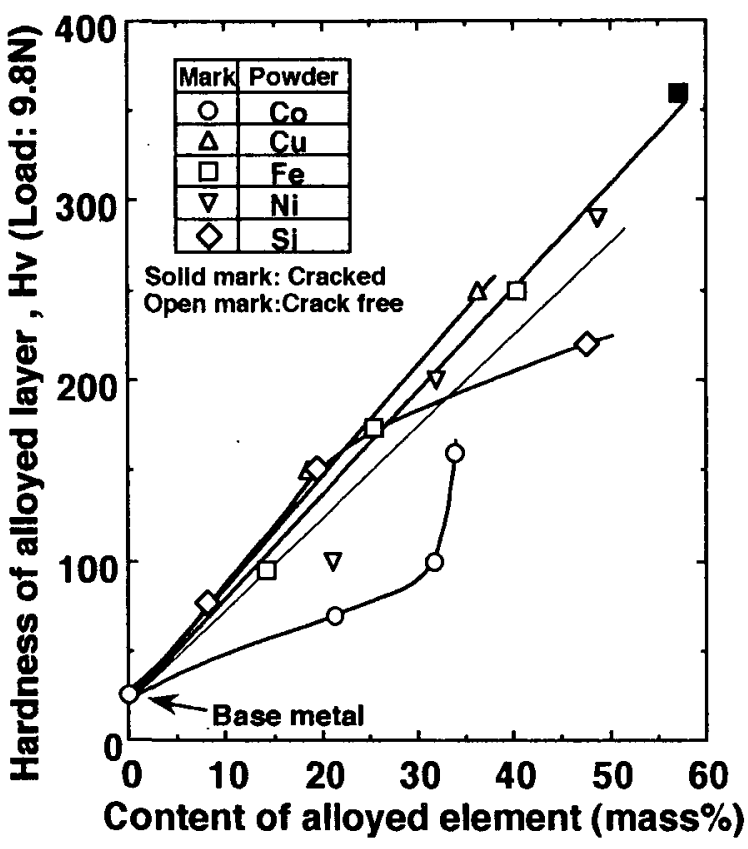

図4 金属粉末添加 PTA 法による硬化層の硬さと添加金 属量との関係
Type I

Particle dispersed composite layer is formed in fusion zone.

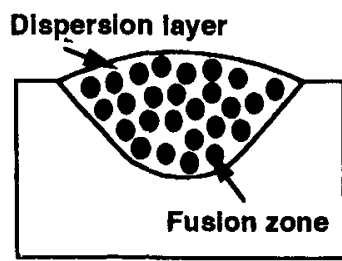

$\mathrm{TiC}, \mathrm{B}_{4} \mathrm{C}, \mathrm{SiC}, \mathrm{VC}, \mathrm{NbC}$, MorC, TaC,WC
Type II Compound layer is
formed on the upper
part of fusion zone.

Compound layer

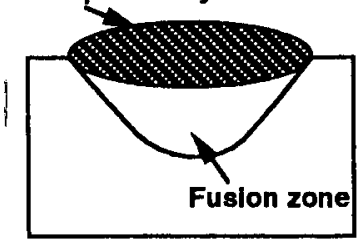

$\mathrm{Cr}_{3} \mathrm{C}_{2}$
図 5 炭化物セラミックス粉末添加により得られる複合化 層の代表的な形態分類（断面組織の模式図） 


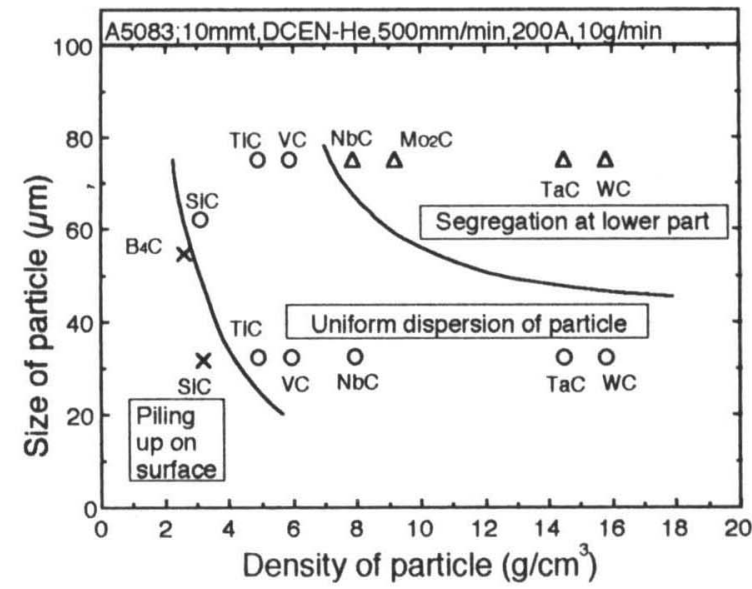

図 6 PTA 複合化層内における炭化物粒子の分散状態に 及ぼす粒子径と比重の影響

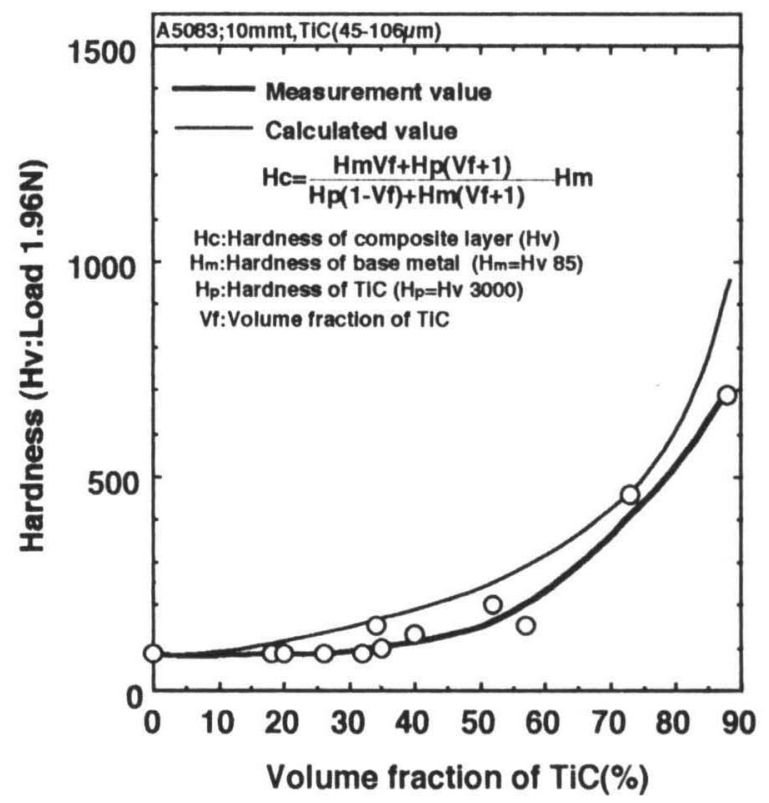

図 $7 \mathrm{TiC}$ 粒子分散複合化層の硬さと $\mathrm{TiC}$ 体積率との 関係

これは一層盛法では粉末供給量を増加しても, 複合化層 内への混入の程度には限界が存在するためである。困 $7^{55}$ は,このようにして得られた複合化層の $\mathrm{TiC}$ 体積率 と硬さの関係を示す。両者の関係は粒子分散型の複合則 にほぼ従っており，硬さは Ti 体積率が約 $50 \%$ 以上にお いて急激に増加する。

\section{7. 金属-セラミックス複合硬化層の形成とその特性}

これまでに述べたように，金属添加では HV 500〜 700 の合金化層を比較的に容易に得ることができるが, 割れが発生しやすい欠点がある。このため, 割れがない 状態で HV 300 以上の硬さを得ることは困難である。ま たセラミックス添加では Al マトリックスの強度が弱いた めに, セラミック添加のみでは硬さおよび耐摩耗性の著し

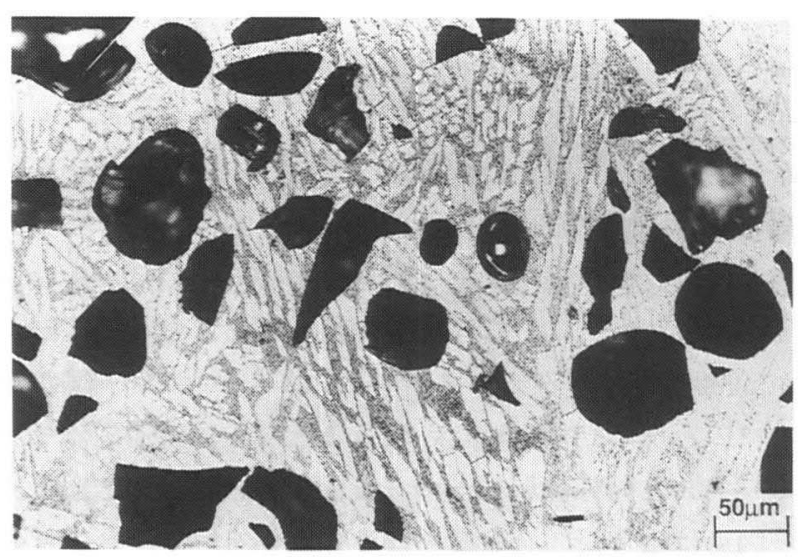

図 8 銅と $\mathrm{TiC}$ の複合添加により得られた PTA 複合硬 化層のミク口組織（黒い粒子：TiC，白い粒子： $\mathrm{CuAl}_{2}$, 灰色部: $\mathrm{Al}+\mathrm{CuAl}_{2}$ )

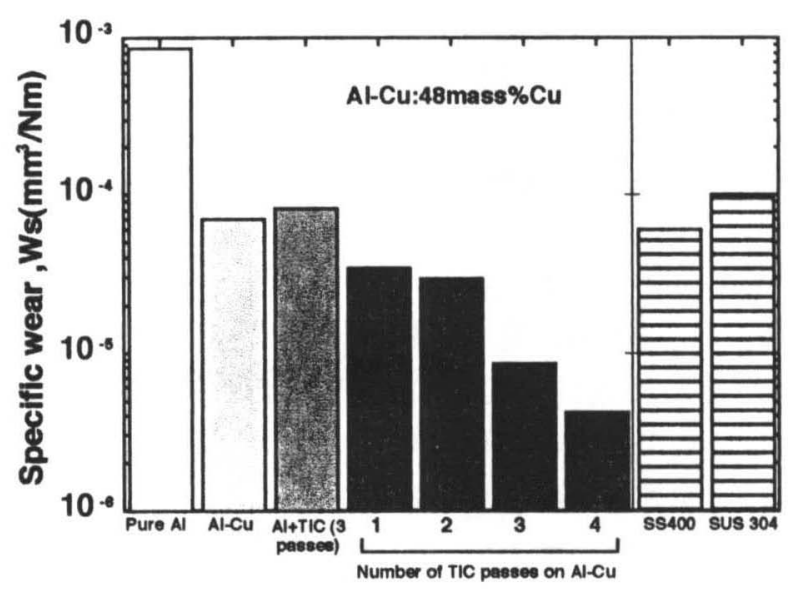

図 9 銅単独添加, $\mathrm{TiC}$ 単独添加および銅 $+\mathrm{TiC}$ 複合添加 層の比摩耗量 Ws と母材純 $\mathrm{Al}$ および鉄鋼材料（軟 鋼 SS 400, ステンレス鋼 SUS 304) との比較（大越 式迅速摩耗試験)

い向上は望めない。このため，両者の同時添加による重畳 効果が有効であると考えられる。すなわち金属添加によ ク，硬化層を形成することにより $\mathrm{Al}$ マトリックスの強化 を図り，そこに硬質セラミックス粒子を添加することによ ク，両者のハイブリット硬化層を形成する方法である.

図 $8^{5}$ はその代表例として金属に銅，七ラミックスに $\mathrm{TiC}$ を複合添加したハイブリッド層のミクロ組織を示

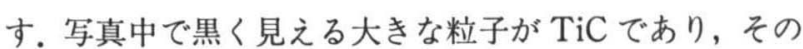
周囲を白色の棒状化合物である $\theta\left(\mathrm{CuAl}_{2}\right)$ 相と, さらに 両者の吵間を $\theta$ 相とアルミニウムとの共晶が完全に埋 めている.このような緻密な組織を呈しているために, 硬さは HV 550 に達しており, 割れは認められない.また 困 $9^{5)}$ は, 耐摩耗性を銅および $\mathrm{TiC}$ 単独添加層と比較し たものである。摩耗試験は大越式迅速摩耗試験により評 価した，銅および TiC 単独添加では，耐摩耗性はそれぞ れ母材アルミニウムの約 10 倍にまで改善される.しかし 
これ以上の改善は得られなかった。これに对して，複合 添加ではさらに一段と耐摩耗性が向上し，母材アルミニ ウムの約 100 倍以上にまで改善される。

なお複合添加の方法には，金属粉末およびセラミック 又粉末を同時に PTA 法で添加する方法のほかに，金属 添加をたとえば銅の場合には， $\mathrm{Al}-\mathrm{Cu}$ 合金棒や $\mathrm{AL}-\mathrm{Cu}$ 複合ワイヤを用いて添加する方法がある。また添加材料 のみならず，添加方法でも，あらかじめティグ法やミグ 法で硬化層を形成後，その上にPTA 法でセラミックス粒 子を添加するなど, 各添加方法の複合化も有効である.

\section{8. お り に}

PTA 法による厚膜硬化層の形成について解説した。 読者の中には，実用的な話を期待していた方も多いと思 j. 現在この分野の話題は多いが現実的に私の知る限り 本方法の実用化は数少ない.

しかしながら，近年ではアルミニウム合金の利用が 種々の分野で進められているもののアルミニウム合金は 鉄鋼材料に比してコストが基本的に高い．そのために， 耐磨耗性のような付加価值をつけることは性能としては 有効であるもののコスト高は避けられない（量との関係 もあるが現状ではコストは高いはず)。
さらにここで示したような技術はノウハウの部分 (耐磨耗性は磨耗状況により要求される性能が大きく異 なるので適正な硬化層を形成しなければならない）が多 いためにあまり表にでてこないのではないかと思う。

ここでは，本方法の可能性について述べることによ ク, 読者の方々が本方法に興味を持たれ, 本方法の適用 を検討し，さらにはアルミニウム合金の利用を検討して いただければ，この解説も有効であったと思う。

\section{参 考 文 献}

1) 溶接学会編：溶接便覧(改訂 3 版), 丸善, 9 章, 462(1977).

2）松田福久, 中田一博, 橋本武典：プラズマアーク粉体アロ イング法による Al 合金表面への $\mathrm{TiC}$ 粒子アロイング層の 形成条件の検討, 溶接学会論文集, 第 13 巻, 3 号, 395 (1995).

3) 橋本武典, 中田一博, 松田福久: 大阪大学溶接工学研究所 高エホルギー溶射研究センター1993 年公開研究シンポシ ウムプロシーディングス, 59 (1993).

4) 橋本武典 : プラズマアーク粉体アロイング法によるアルミ 二ウム合金表面への厚瞙耐磨耗層の形成に関寸る研究，大 阪大学大学院工学研究科学位論文 (1995).

5) K. Nakata, T. Hashimoto, F. Matsuda: "Surface Har. dening of Aluminum Alloy by PTA Overlaying Process", Prof. 1 st Int. Conf. on Proceeding Materials for Properties, Edited by H. Henein and T. Oki, TMS, 1089 (1993).

\title{
短時間、低コスト、適正品質組立技術の展開 一材料、プロセス及び組立設計一
}

\author{
テキスト 3,000 円 \\ ご注文その他については下記へお問い合わせ下さい． \\ 社団法人 溶接学会 \\ 干101-0025 東京都千代田区神田佐久間 1-11 \\ 803-3253-0488 ファックス03-3253-3059
}

